\title{
FAKTOR YANG MEMPENGARUHI KENAIKAN DAN PENURUNAN SISA HASIL USAHA (SHU) KOPERASI SYARIAH ${ }^{1)}$
}

\author{
Farokhah Muzayinatun Niswah \\ Mahasiswa Program Studi Ekonomi Islam-Fakultas Ekonomi dan Bisnis-Universitas Airlangga \\ Email: farokhah.muzayinatun-13@feb.unair.ac.id
}

Dina Fitrisia Septiarini

Departemen Ekonomi Syariah-Fakultas Ekonomi dan Bisnis-Universitas Airlangga

Email: dina.fitrisia@feb.unair.ac.id

\begin{abstract}
:
The pupose of this research is to determines the effects of own equity, assets and financing income as the factors of increase and decrease in cooperative surplus on KJKS Ben Iman Lamongan.

The approach used in this study is the quantitative approach. Data analysis techniques used in this research is multiple linear regression analysis. The sampling method used in this study is purposive sampling, the sample is KJKS Ben Iman Lamongan. The author uses secondary data from monthly reports of balance sheet and the calculation surplus of operations of the period January 2014 to December 2016.

The results of this study are own equity and assets partially no significant effect on the cooperative surplus distribution, financing income partially significant affect the cooperative surplus distribution and own equity, assets and financing income simultaneously affect the cooperative surplus distribution amounted to $93.13 \%$ while the rest $6,87 \%$ determined by other variables.
\end{abstract}

Keyword: Own Equity, Assets, Financing Income, Cooperative Surplus

\section{PENDAHULUAN}

\section{Latar Belakang}

Menurut data sensus penduduk tahun 2015 penduduk Indonesia yang berjumlah 237.641.326 jiwa dengan penduduk miskin sebesar $11,13 \%$. Sebuah negara tentu menginginkan penduduknya hidup tentram dan sejahtera. Angka ini termasuk besar sehingga keberadaan koperasi diharapkan dapat membantu meringankan beban masyarakat, mengingat koperasi merupakan lembaga keuangan non bank yang diperuntukkan untuk membantu masyarakat golongan menengah ke bawah. Berdasarkan Pasal 3 Undang-Undang No.25 Tahun 1992 tentang Perkoperasian, fungsi koperasi adalah meningkatkan kesejahteraan para anggota pada khususnya dan masyarakat pada umumnya, serta ikut serta membangun perekonomian nasional untuk mewujudkan masyarakat yang maju, adil, dan makmur berlandaskan Pancasila dan UUD 1945. Selain itu, koperasi penting keberadaannya karena perbankan belum mampu memenuhi kebutuhan masyarakat menengah ke bawah (Subagyo, 2015:6).

Seiring dengan berjalannya waktu, banyaknya bermunculan institusi kevangan berbasis Islam yang mengharamkan adanya bunga karena tergolong ke dalam riba yang hukumnya haram dalam Islam. Kondisi ini meningkatkan kesadaran dan minat masyarakat untuk mematuhi perintah agama yaitu menjauhi riba. Mayoritas penduduk Indonesia yang beragama

1) Jurnal ini adalah bagian dari skripsi Farokhah Muzayinatun Niswah NIM.041311433178 yang diuji pada 31 Januari 2017 
Niswah, et al/Jurnal Ekonomi Syariah Teori dan Terapan Vol. 4 No. 12 Desember 2017: 937-951; FAKTOR YANG MEMPENGARUHI KENAIKAN DAN PENURUNAN SISA HASIL USAHA (SHU) KOPERASI SYARIAH

Islam menjadikan peluang besar berdirinya lembaga kevangan Islam. Sehingga institusi keuangan berbasis syariah berkembang begitu pesat dan cepat di Indonesia, salah satunya adalah koperasi syariah. Salah satu bentuk koperasi syariah adalah Koperasi Jasa Kevangan Syariah atau biasa disingkat dengan KJKS (Burhanuddin: 2013,131).

Sebagai makhluk ciptaan Allah SWT, kita dianjurkan untuk menjadi orang yang bermanfaat dan saling membantu satu sama lain. Melalui KJKS, masyarakat yang mempunyai dana lebih dapat membantu masyarakat lain yang kekurangan dana dengan tidak memberikan syarat dan ketentuan-ketentuan yang rumit. Allah SWT berfirman dalam Al-Qur'an Surat AlMaidah (5) ayat 2 yang artinya ....Dan tolong-menolonglah kamu dalam (mengerjakan) kebaikan dan takwa, dan jangan tolong-menolong dalam berbuat dosa dan permusuhan. Bertakwalah kepada Allah, sungguh, Allah sangat berat siksa-Nya. (Departemen Agama Rl, 2005:106).

KJKS memiliki peran penting dalam perekonomian Indonesia sama halnya dengan koperasi dan lembaga keuangan pada umumnya. Sehingga perlunya optimalisasi kerja dan kinerja lembaga ini guna meningkatkan kesejahteraan masyarakat. Salah satu tolak ukur yang digunakan koperasi, baik koperasi syariah maupun konvensional untuk menilai tingkat kesejahteraan anggotanya adalah melalui jumlah sisa hasil usaha. Menurut Undang-Undang No. 25 Tahun
1992 tentang Perkoperasian Pasal 45 Ayat 1. Sisa Hasil Usaha (SHU) adalah pendapatan koperasi yang didapat dalam satu tahun buku dikurangi biaya, penyusutan, dan kewajiban-kewajiban lain, termasuk pajak yang harus dibayarkan dalam tahun buku tersebut.

Begitu pentingnya SHU dalam koperasi, sehingga banyak peneliti yang melakukan penelitian akan beberapa faktor yang mampu mempengaruhi SHU yang akan dibagikan kepada anggota koperasi syariah. Seperti penelitian yang dilakukan oleh Windarti (2010) dalam skripsinya yang berjudul Analisis FaktorFaktor yang Mempengaruhi Sisa Hasil Usaha (SHU) pada KPRI di Kabupaten Wonogori Tahun 2009. Hasil dari penelitian ini menunjukkan bahwa modal sendiri, modal pinjaman, partisipasi usaha anggota, dan jumlah pengurus koperasi secara positif berpengaruh terhadap besar SHU pada Koperasi Pegawai Negeri di Kabupaten Wonogiri.

Penelitian lain juga dilakukan Winarko (2014) yang telah melakukan penelitian dengan judul Pengaruh Modal Sendiri, Jumlah Anggota, dan Aset terhadap Sisa Hasil Usaha pada Koperasi Kediri. Hasil penelitian ini menunjukkan bahwa modal sendiri secara parsial berpengaruh terhadap SHU, jumlah anggota secara parsial berpengaruh terhadap SHU, dan aset secara parsiap berpengaruh terhadap SHU. Sedangkan variabel yang paling dominan mempengaruhi SHU adalah aset. Modal sendiri, jumlah 
Niswah, et al/Jurnal Ekonomi Syariah Teori dan Terapan Vol. 4 No. 12 Desember 2017: 937-951; FAKTOR YANG MEMPENGARUHI KENAIKAN DAN PENURUNAN SISA HASIL USAHA (SHU) KOPERASI SYARIAH

anggota, dan aset secara simultan berpengaruh terhadap SHU.

Oleh karena itu penulis tertarik melakukan penelitian dengan mengangkat topik tentang pengaruh modal sendiri, aset dan pendapatan pembiayaan terhadap pembagian Sisa Hasil Usaha (SHU) koperasi syariah.

\section{LANDASAN TEORI}

Koperasi syariah adalah bentuk koperasi yang sesuai dengan syariah Islam. Buchori (2012:7) mendefinisikan koperasi syariah sebagai sebuah perubahan dari koperasi konvensional melalui pendekatan yang sesuai dengan aturan Islam dan mencontoh kegiatan ekonomi yang dilakukan Rasulullah dan para sahabatnya karena secara umum prinsip operasional koperasi konvensional adalah membantu mensejahteraan para anggotanya dalam bentuk gotong royong dan sudah tentu prinsip tersebut tidak menyimpang dari syariah. Sedangkan Koperasi Jasa Keuangan Syariah (KJKS) adalah koperasi yang kegiatan usahanya bergerak di bidang pembiayaan, investasi, dan simpan pinjam dengan prinsip bagi hasil (syariah) (Sholihin, 2008:424). Dengan prinsip gotong royong (ta 'waun ala birri) dan bersama-sama dalam membangun kehidupan yang mandiri, perlu adanya proses internalisasi terhadap pola pemikiran dan tata cara pengelolaan usaha, produk-produk yang ditawarkan, dan hukum yang diberlakukan harus sesuai dengan syariah.
Koperasi syariah didirikan secara bersama-sama oleh dua orang atau lebih yang masing-masing memberikan kontribusi dana dan berpartisipasi dalam kerja dengan dalam porsi yang sama besar. Masing-masing partner saling menanggung satu sama lain dalam hak dan kewajiban. Dan tidak diperbolehkan salah seorang memberikan modal yang lebih besar dan memperoleh keuntungan yang lebih besar pula dibanding dengan partner lainnya. Asas usaha koperasi syariah berdasarkan konsep gotong royong. Sehingga dalam keuntungan ataupun kerugian yang diperoleh harus dibagi sama rata. Semua kegiatan usaha dan operasionalnya harus sesuai dengan kesepakatan bersama melalui Rapat Anggota Tahunan (RAT) yang melibatkan seluruh anggota koperasi (Buchori, 2012:78).

Koperasi syariah berbeda dengan koperasi konvensional pada umumnya. Begitu pula dalam usaha yang dijalankan oleh koperasi syariah berbeda dengan koperasi konvensional pada umumnya. Ada beberapa ketentuan usaha yang dijalankan koperasi syariah (Sholihin, 2008:427):

1. Usaha koperasi syariah meliputi semua kegiatan usaha yang halal, baik dan bermanfaat (thayyib) serta menguntungkan dengan menggunakan sistem bagi hasil dan bebas dari riba, judi atau ketidakjelasan (gharar).

2. Untuk menjalankan fungsi perannya, koperasi syariah menjalankan 
usahanya sesuai dengan yang ada dalam sertifikasi usaha koperasi.

3. Usaha-usaha yang diselenggarakan koperasi syariah tidak bertentang dengan perundang-undangan yang berlaku.

Menurut Sholihin (2008:424) koperasi memiliki peran dan fungsi sebagai berikut:

1. Membangun dan mengembangkan potensi serta kemampuan anggota pada khususnya, dan masyarakat pada umumnya, untuk meningkatkan kesejahteraan ekonominya.

2. Memperkuat kualitas sumber daya manusia anggota, sehingga menjadi lebih amanah, profesional (fathonah), konsisten, dan konsekuen (istiqomah) dalam menerapkan prinsip-prinsip ekonomi Islam.

3. Berusaha untuk mewujudkan dan mengembangkan perekonomian nasional yang merupakan usaha milik bersama berasaskan kekeluargaan dan demokrasi ekonomi.

4. Sebagai perantara antara penyedia dana dan pengguna dana, sehingga tercapai optimalisasi pemanfaatan harta.

5. Menguatkan kelompok-kelompok anggota sehingga dapat bekerja sama melakukan kontrol terhadap koperasi secara efektif.

6. Mengembangkan dan memperluas kesempatan kerja bagi masyarakat.

7. Menumbuhkembangkan usaha-usaha produktif para anggota.

Pada koperasi, yang menjadi tolak ukur kesejahteraan anggotanya adalah melalui SHU. Menurut Sitio dan Halomoan (2001:87), Sisa Hasil Usaha (SHU) dari aspek ekonomi merupakan selisih dari seluruh pemasukan atau penerimaan total (total revenue) dengan biaya-biaya atau biaya total (total cost) dalam satu tahun buku. Sedangkan dari aspek legalistik, SHU menurut Undang-undang No.25 Tahun 1992 tentang Perkoperasian Bab IX Pasal 45 adalah:

1. SHU koperasi adalah pendapatan koperasi yang diperoleh dalam satu tahun buku dikurangi biaya, penyusutan, dan kewajiban lain termasuk pajak dalam tahun buku yang bersangkutan.

2. SHU setelah dikurangi dana cadangan, dibagikan kepada anggota sebanding jasa usaha yang dilakukan oleh masing-masing anggota dengan koperasi, serta digunakan untuk keperluan pendidikan perkoperasian dan keperluan koperasi, sesuai dengan keputusan Rapat Anggota.

3. Besarnya pemupukan modal dana cadangan ditetapkan dalam Rapat Anggota.

Besarnya SHU yang diperoleh suatu koperasi dapat mencerminkan bahwa koperasi tersebut telah dikelola dengan baik dan professional (Windarti, 2010:5). Sedangkan penetapan besarnya pembagian SHU kepada para anggota tidaklah sama, tergantung besarnya partisipasi modal dan transaksi anggota terhadap pembentukan pendapatan koperasi. Agar tercermin asas keadilan, 
Niswah, et al/Jurnal Ekonomi Syariah Teori dan Terapan Vol. 4 No. 12 Desember 2017: 937-951; FAKTOR YANG MEMPENGARUHI KENAIKAN DAN PENURUNAN SISA HASIL USAHA (SHU) KOPERASI SYARIAH

demokrasi, transparansi, dan sesuai dengan prinsip-prinsip koperasi, terdapat prinsip-prinsip pembagian SHU (Sitio dan Halomoan, 2001:91):

1. SHU yang dibagi adalah yang berasal dari anggota.

1. Pada hakekatnya SHU yang dibagikan kepada para anggota berasal dari anggota sendiri, sedangkan SHU yang bukan berasal dari transaksi anggota tidak dibagikan kepada anggota tetapi menjadi dana cadangan koperasi.

2. SHU anggota adalah jasa dari modal maupun transaksi usaha yang dilakukan anggota sendiri.

SHU yang diterima anggota koperasi pada dasarnya merupakan tambahan penghasilan dari dana yang diinvestasikan oleh anggota dan juga hasil transaksi yang dilakukan oleh koperasi. Sehingga perlu ditentukannya proporsi SHU untuk jasa modal dan jasa transaksi usaha yang akan dibagikan kepada setiap anggota. Penentuan proporsi SHU tersebut disepakati bersama dalam rapat anggota.

3. Pembagian SHU anggota dilakukan secara transparan.

Proses penghitungan SHU tiap anggota dan jumlah SHU yang dibagikan harus diumumkan secara transparan, sehingga terbangun rasa kebersamaan, kepemilikan, dan demokrasi antar anggota dalam koperasi.

4. SHU anggota dibayar secara tunai.
SHU yang dibagikan kepada anggota haruslah dalam bentuk tunai, sehingga koperasi dapat membuktikan dirinya sebagai suatu usaha yang sehat kepada anggota, masyarakat, dan mitra bisnisnya.

Dasar hukum koperasi Indonesia adalah pasal 5 ayat 1 Undang-Undang No.25 Tahun 1992 tentang Perkoperasian yang menyatakan bahwa pembagian SHU kepada masing-amsing anggota dilakukan bukan hanya sesuai dengan porsi modal yang disetor, tetapi juga berdasarkan jasa usaha anggota yang diberikan kepada koperasi.

Sisa hasil usaha dapat dirumuskan sebagai berikut:

$S H U=T R-(\operatorname{Exp}+$ Dep $+K e w+t / z)$

Di mana:

TR = Total Revenue/ Total pendapatan

Exp $=$ Expenses $/$ Pengeluaran

Dep $=$ Depresiasi $/$ Penyusutan

Kew $=$ Kewajiban

$\mathrm{t} / \mathrm{z}=\mathrm{tax}($ pajak $) /$ zakat

Untuk membentuk sebuah koperasi, tentunya dibutuhkan modal yang cukup besar. Modal sangatlah penting bagi suatu usaha atau organisasi. Modal digunakan untuk menjalankankan operasional usaha yang dijalankan.

Undang-undang No. 25 Tahun 1992 tentang Perkoperasian Bab VII Pasal 41 disebutkan bahwa modal koperasi terdiri dari modal sendiri dan modal pinjaman atau modal luar. Modal sendiri bersumber dari simpanan pokok, simpanan wajib, dana cadangan, dan donasi. Sedangkan modal luar bersumber dari anggota, koperasi, bank, lembaga keuangan non- 
Niswah, et al/Jurnal Ekonomi Syariah Teori dan Terapan Vol. 4 No. 12 Desember 2017: 937-951; FAKTOR YANG MEMPENGARUHI KENAIKAN DAN PENURUNAN SISA HASIL USAHA (SHU) KOPERASI SYARIAH

bank, penerbitan obligasi, dan sumber lain.

Modal sendiri menurut Sitio dan Halomoan (2001:84) terdiri dari:

1. Simpanan pokok anggota, merupakan sejumlah vang yang sama besarnya, yang wajib dibayarkan oleh anggota kepada koperasi pada saat masuk menjadi anggota. Simpanan pokok tidak dapat diambil selama yang bersangkutan masih menjadi anggota.

2. Simpanan wajib, merupakan sejumlah simpanan tertentu yang tidak harus sama besarnya, yang wajib dibayarkan oleh anggota kepada koperasi pada periode tertentu. Simpanan wajib tidak dapat diambil selama yang bersangkutan masih menjadi anggota.

3. Dana cadangan, merupakan sejumlah dana yang diperoleh dari penyisihan Sisa Hasil Usaha (SHU) dan dicadangkan untuk menutupi kekurangan bila koperasi mengalami kerugian.

4. Donasi atau hibah, merupakan sejumlah uang atau barang dengan nilai tertentu yang disumbangkan oleh pihak ketiga, tidak ada ikatan dan tidak ada kewajiban untuk mengembalikannya.

Sehingga modal sendiri dapat dirumusukan menjadi:

Modal Sendiri $=\mathrm{SP}+\mathrm{SW}+\mathrm{C}+\mathrm{H}$

Di mana:

$\mathrm{SP}=$ Simpanan Pokok

$\mathrm{SW}=$ Simpanan Wajib
$C$ = Cadangan

$\mathrm{H}=$ Hibah/donasi

Menurut Widiyanti (dalam Winarko, 2014:156) modal sendiri bagi koperasi merupakan sumber permodalan yang utama karena beberapa alasan berikut:

1. Alasan Kepemilikan

Modal yang bersumber dari anggota koperasi merupakan salah satu bentuk kepemilikan anggota terhadap koperasi beserta usahanya. Karena mereka merasa ikut memiliki koperasi, maka mereka akan lebih bertanggungjawab untuk menjaga keberhasilan usaha koperasi tersebut.

\section{Alasan Ekonomi}

Modal yang berasal dari anggota akan dapat digunakan dan dikembangkan oleh koperasi dengan lebih efisien dan murah karena tidak ada biaya tambahan yang harus dikembalikan atas penggunaan modal tersebut.

3. Alasan Risiko

Modal sendiri atau anggota memiliki resiko yang lebih kecil dibandingkan dengan modal dari luar, terutama pada saat usaha tidak berjalan dengan lancar.

Seperti halnya modal sendiri, bagi koperasi aset merupakan suatu komponen penting. Menurut Wiyono dan Maulamin (2012:86) aset adalah sumber daya yang dimiliki oleh entitas syariah sekarang yang timbul dari peristiwa masa lalu dan diharapkan mendapat manfaat ekonomi di masa depan.

Menurut Supriyanto (2015:130-131) aset terbagi menjadi aset lancar, penyertaan, 
Niswah, et al/Jurnal Ekonomi Syariah Teori dan Terapan Vol. 4 No. 12 Desember 2017: 937-951; FAKTOR YANG MEMPENGARUHI KENAIKAN DAN PENURUNAN SISA HASIL USAHA (SHU) KOPERASI SYARIAH

investasi, aset tetap dan aset tidak berwujud, berikut penjelasannya:

1. Aset lancar (current asset), yaitu aset yang diharapkan menjadi kas, dijual, dikonsumsikan, dan digunakan dalam waktu kurang dari satu tahun.

2. Penyertaan, yaitu simpanan yang berhubungan dengan keanggotaan tingkat primer pada sekunder yang menrupakan simpanan wajib disetor secara rutin. Terdiri dari simpanan pokok, simpanan wajib, simpanan kapitalisasi, simpanan sukarela yang diberlakukan sebagai saham.

3. Investasi, sejumlah dana yang ditanamkan kepada proyek-proyek tertentu, seperti investasi pada suratsurat berharga, investasi dalam bentuk penyisihan dana seperti untuk dana pensiun karyawan atau pelunasan hutang jangka panjang, investasi pada tanah yang tidak digunakan dalam kegiatan operasional.

4. Aset tetap (fixed asset), adalah aset yang dimiliki dari proses pembelian atau pertukaran yang digunakan dalam kegiatan operasional.

5. Aset tidak berwujud (intangible of fixed asset), adalah aset yang tidak memiliki wujud fisik seperti hak paten, hak cipta, goodwill, merek dagang, dan lain sebagainya.

Salah satu bentuk koperasi syariah adalah Koperasi Jasa Kevangan Syariah (KJKS). KJKS mempunyai kegiatan utama yaitu kegiatan pendanaan dan pembiayaan. Melalui kegiatan pembiayaan koperasi akan mendapatkan pendapatan pembiayaan.

Pembiayaan dalam prinsip syariah menurut Undang-Undang Nomor 10 Tahun 1998 tentang Perubahan PerundangUndangan Nomor 7 Tahun 1997 tentang Perbankan adalah penyediaan vang atau tagihan berdasarkan persetujuan dan kesepakatan antara bank dengan pihak lain yang mewajibkan pihak yang dibiayai untuk mengembalikan vang atau tagihan tersebut setelah jangka waktu tertentu dengan imbalan atau bagi hasil.

Sedangkan pendapatan menurut Ikatan Akuntansi Indonesia (2007:261) adalah penghasilan yang timbul dari aktivitas perusahaan, seperti penjualan, penghasilan jasa (fees), bunga, dividen, royalti, dan sewa. Pendapatan diakui jika ada kemungkinan besar manfaat ekonomi yang diperoleh perusahaan di masa depan dan manfaat tersebut dapat diukur dengan andal.

Pendapatan pembiyaan adalah pendapatan yang berasal dari kegiatan pembiayaan yang dilakukan oleh koperasi syariah kepada para anggota. Penyaluran dana dalam kegiatan pembiayaan akan menghasilkan pendapatan pembiayaan. Pendapatan pembiayaan dapat ditemukan di Laporan Perhitungan Hasil Usaha pada koperasi syariah. Laporan perhitungan usaha memuat informasi tentang pendapatan dan beban-beban usaha dan beban perkoperasian selama periode tertentu dengan hasil akhir didapatkan sisa hasil usaha. Laporan hasil usaha hampir sama 
Niswah, et al/Jurnal Ekonomi Syariah Teori dan Terapan Vol. 4 No. 12 Desember 2017: 937-951; FAKTOR YANG MEMPENGARUHI KENAIKAN DAN PENURUNAN SISA HASIL USAHA (SHU) KOPERASI SYARIAH

dengan laporan laba rugi pada laporan keuangan perusahaan pada umumnya.

Berdasarkan penjelasan teori di atas, maka didapatkan beberapa hipotesis sebagai berikut:

1. Menurut Widiyanti (dalam Winarko, 2014:156) modal sendiri adalah sumber modal utama dari sebuah koperasi syariah. Untuk memenuhi kebutuhan koperasi dan anggotanya serta memaksimalkan produk atau program yang ditawarkan oleh koperasi tentu membutuhkan dana yang cukup besar. Semakin banyak modal yang dimiliki koperasi maka koperasi akan dapat mengembangkan usahanya. Sehingga semakin besar modal yang dimiliki akan semakin besar pula Sisa Hasil Usaha (SHU) yang dibagikan kepada para anggota koperasi (Windarti, 2010:42).

2. Aset merupakan cerminan kekayaan suatu lembaga atau organisasi, begitu juga koperasi syariah. Koperasi harus mampu mengatur kebutuhan koperasi dengan baik sehingga biaya yang dikeluarkan untuk pemenuhan kebutuhan koperasi dapat dikontrol (Winarko, 2014:152). Semakin besar aset yang dimiliki koperasi syariah, maka Sisa Hasil Usaha (SHU) yang dibagikan kepada anggota juga akan semakin besar.

3. Sesuai dengan penghitungan SHU menurut Sitio dan Halomoan (2001:92), untuk mengetahui besarnya SHU yang diperoleh koperasi syariah, dapat diperoleh dari total pendapatan (dari penjualan, penerimaan jasa dan pendapatan lain) dikurangi harga pokok penjualan, beban operasional, beban administrasi dan umum dan pajak penghasilan. Pendapatan yang berasal dari pembiayaan koperasi syariah masuk ke dalam total pendapatan. Sedangkan total pendapatan proporsional dengan SHU, sehingga semakin banyak pendapatan pembiayaan yang diperoleh oleh koperasi syariah, maka SHU yang diperoleh juga akan semakin banyak.

\section{METODE PENELITIAN}

Jenis data yang digunakan dalam penelitian ini adalah data sekunder berupa data time series. Data sekunder menurut Wibisono (2003:119) adalah data yang didapat dan disimpan orang lain yang biasanya merupakan data masa lalu atau data historis. Data sekunder biasanya dikumpulkan oleh lembaga pengumpul data dan dipublikasikan kepada masyarakat. Data-data yang dibutuhkan dalam penelitian ini adalah laporan keuangan bulanan KJKS Ben Iman Lamongan, yaitu neraca dan laporan perhitungan hasil usaha.

Data yang diambil dari laporan keuangan bulanan KJKS Ben Iman Lamongan yaitu modal sendiri, aset, pendapatan pembiayaan dan Sisa Hasil Usaha (SHU). Periode yang diambil dalam penelitian ini adalah bulan Januari 2014 sampai bulan Desember 2016. Sumber data pada penelitian ini diperoleh langsung oleh penulis dari kantor KJKS Ben 
Niswah, et al/Jurnal Ekonomi Syariah Teori dan Terapan Vol. 4 No. 12 Desember 2017: 937-951; FAKTOR YANG MEMPENGARUHI KENAIKAN DAN PENURUNAN SISA HASIL USAHA (SHU) KOPERASI SYARIAH

Iman Lamongan di Jalan Veteran No.80 Lamongan.

Populasi yang digunakan dalam penelitian ini adalah koperasi syariah yang terdaftar di Dinas Koperasi Kabupaten Lamongan, yaitu sebanyak 30 koperasi syariah. Metode pemilihan sampel pada penelitian ini adalah menggunakan purposive sampling atau selected sampling. Sampel yang digunakan adalah KJKS Ben Iman Lamongan. Peneliti meyakini bahwa sampel yang dipilih dapat memenuhi data yang dibutuhkan dalam penelitian yang dilakUkan. KJKS Ben Iman sebagai sampel dalam penelitian ini menurut penulis sudah memenuhi kriteria karena:

1. Merupakan koperasi yang menerapkan prinsip syariah dari awal berdiri (bukan dari konvensional diubah ke syariah).

2. Merupakan koperasi syariah tertua di Lamongan.

3. Termasuk koperasi syariah terbesar di Lamongan dan telah memiliki 4 cabang di kecamatan-kecamatan Lamongan.

4. Memiliki aset koperasi yang besar, yaitu sebesar Rp34.887.478.394 (periode Desember 2016).

5. Memiliki semua data yang dibutuhkan untuk penelitian, yaitu data bulanan atas modal sendiri, aset, pendapatan pembiayaan dan SHU koperasi syariah dalam bentuk data rasio pada periode Januari 2014 sampai Desember 2016 (36 sampel).
Teknik analisis data yang digunakan dalam penelitian ini adalah analisis regresi linier berganda (Multiple Linier Regression Analysis). Model regresi linier berganda digunakan karena variabel eksogen yang digunakan sebanyak 3 variabel atau lebih dari satu yang tujuannya adalah untuk dapat menjelaskan pengaruh variabel pendapatan pembiayaan, modal sendiri dan aset terhadap variabel Sisa Hasil Usaha (SHU) pada KJKS Ben Iman Lamongan. Dalam melakukan analisis regresi linier berganda, metode ini mensyaratkan untuk melakukan uji asumsi klasik guna mengetahui apakah data dalam penelitian ini telah memenuhi asumsi regresi linier atau tidak.

Persamaan regresi dalam penelitian ini dapat dirumuskan sebagai berikut:

$Y=a+\beta_{1} X_{1}+\beta_{2} X_{2}+\beta_{3} X_{3}+$ et

Di mana:

$$
\begin{array}{lll}
\mathrm{Y} & =\text { Sisa Hasil Usaha (SHU) } \\
\mathrm{a} & =\text { Konstanta } \\
\mathrm{X}_{2} & =\text { Modal Sendiri } \\
\mathrm{X}_{2} & =\text { Aset } \\
\mathrm{X}_{3} & =\text { Pendapatan pembiayaan } \\
\beta_{1} \ldots . . \beta_{4} & =\text { Koefisien regresi } \\
\text { et } & =\text { Error term/ variabel } \\
& & \text { pengganggu }
\end{array}
$$

\section{HASIL DAN PEMBAHASAN}

Sebelum dilakukan uji regresi linier berganda, dilakukan uji asumsi klasik. Uji asumsi klasik yang dilakukan meliputi uji: normalitas, autokorelasi, heterokedastisitas dan multikolinieritas. Hasil uji asumsi klasik yang dilakukan mengindikasikan bahwa kondisi BLUE (Best Linier Unbias Estimator) telah tercapai setelah dilakukan transformasi Cochrane Orcutt dengan 
Niswah, et al/Jurnal Ekonomi Syariah Teori dan Terapan Vol. 4 No. 12 Desember 2017: 937-951; FAKTOR YANG MEMPENGARUHI KENAIKAN DAN PENURUNAN SISA HASIL USAHA (SHU) KOPERASI SYARIAH

dua langkah Robust. Hasil uji asumsi klasik tersebut tidak disertakan dalam jurnal ini.

Langkah selanjutnya melakukan analisis regresi linier berganda. Uji ini terdiri dari uji t, uji F dan R2. Gambar pada lampiran menampilkan keluaran dari uji regresi yang telah dilakukan dengan menggunakan perangkat lunak STATA Statistic Data Analysis 11.2.

Pengaruh Modal Sendiri dengan Sisa Hasil Usaha (SHU)

Modal sendiri adalah sumber modal utama dari sebuah koperasi syariah. Modal sendiri bersumber dari simpanan pokok, simpanan wajib, dana cadangan, dan donasi. Simpanan pokok dan simpanan wajib didapatkan dari para anggota di koperasi syariah, simpanan pokok dibayarkan pada awal menjadi anggota sedangkan simpanan wajib dibayarkan tiap bulannya kepada koperasi syariah. Dana cadangan didapatkan dari bagian sisa hasil usaha periode sebelumnya. Donasi didapatkan dari hadiah atau pemberian dari orang yang ingin menghibahkan hartanya kepada koperasi syariah untuk kemajuan koperasi tersebut. Modal sendiri dipengaruhi oleh beberapa faktor. Nafisa (2015) dalam penelitiannya yang berjudul Faktor-Faktor yang Mempengaruhi Modal Sendiri pada Koperasi menunjukkan bahwa ukuran koperasi, umur koperasi, jenis koperasi dan profitabilitas berpengaruh positif terhadap modal sendiri koperasi.

Berdasarkan hasil uji t, didapatkan nilai † hitung dari variabel modal sendiri sebesar $-0,17$ sedangkan nilai † tabel 0,042 sehingga nilai t hitung lebih kecil dari nilai $\dagger$ tabel dan nilai signifikansi sebesar 0,867 atau lebih kecil dari 0,05. Dapat disimpulkan bahwa tidak terdapat pengaruh yang signifikan secara parsial antara modal sendiri dengan Sisa Hasil Usaha (SHU) pada KJKS Ben Iman Lamongan. Perubahan jumlah modal sendiri KJKS Ben Iman tidak mempengaruhi besar kecilnya SHU yang akan dibagikan kepada para anggota.

Hasil pada penelitian ini didukung oleh penelitian yang dilakukan oleh Sari dan Bany (2012) tentang Pengaruh Modal Sendiri, Modal Luar, dan Volume Usaha pada Sisa Hasil Usaha Koperasi di Provinsi Daerah Istimewa Yogyakarta. Dalam penelitian tersebut didapatkan hasil bahwa modal sendiri, modal luar, dan volume usaha secara bersama-sama memengaruhi SHU, sedangkan secara parsial hanya volume usaha yang memengaruhi SHU koperasi. Yang berarti variabel modal sendiri tidak berpengaruh signifikan secara parsial terhadap SHU koperasi.

Modal sendiri tidak berpengaruh signifikan secara parsial terhadap SHU pada KJKS Ben Iman Lamongan disebabkan karena jumlah anggota koperasi yang dimiliki tidak banyak mengalami perubahan dari periode satu ke lainnya (cenderung konstan). Hal ini menyebabkan modal sendiri yang masuk koperasi tidak banyak mengalami perubahan atau bahkan sama, karena setiap anggota baru diharuskan 
Niswah, et al/Jurnal Ekonomi Syariah Teori dan Terapan Vol. 4 No. 12 Desember 2017: 937-951; FAKTOR YANG MEMPENGARUHI KENAIKAN DAN PENURUNAN SISA HASIL USAHA (SHU) KOPERASI SYARIAH

membayar simpanan pokok dan simpanan wajib yang merupakan bagian dari modal sendiri. Jika jumlah anggota tidak mengalami perubahan, maka modal sendiri yang dimiliki juga tidak akan mengalami perubahan. Hal tersebut menyebakan hasil penelitian yang seharusnya modal sendiri berpengaruh signifikan secara parsial terhadap SHU KJKS Ben Iman Lamongan tidak didapatkan.

\section{Pengaruh Aset dengan Sisa Hasil Usaha} (SHU)

Menurut Wiyono dan Maulamin (2012:86) aset adalah sumber daya yang dimiliki oleh entitas syariah sekarang yang timbul dari peristiwa masa lalu dan diharapkan mendapat manfaat ekonomi di masa depan. Aset terdiri dari aset lancar, investasi jangka panjang, aset tetap, aset tak berwujud, dan aset lainlain. Aset yang digunakan dalam penelitian ini adalah total aset (total aktiva) yang dimiliki koperasi pada neraca.

Berdasarkan hasil uji $t$, didapatkan nilai † hitung dari variabel aset sebesar -0,75 sedangkan nilai † tabel 0,042 sehingga nilai $\uparrow$ hitung lebih kecil dari nilai $\dagger$ tabel dan nilai signifikansi 0,090 atau lebih kecil dari 0,05 , sehingga tidak terdapat pengaruh yang signifikan secara parsial antara aset dengan Sisa Hasil Usaha (SHU) pada KJKS Ben Iman Lamongan. Perubahan jumlah total aset KJKS Ben Iman tidak mempengaruhi besar kecilnya SHU yang akan dibagikan kepada para anggota.
Penelitian yang dapat mendukung hasil pada penelitian ini adalah penelitian yang dilakukan oleh Purwanto (2015) dengan judul Pengaruh Modal Sendiri, Hutang, Volume Usaha, dan Jumlah Aset terhadap Sisa Hasil Usaha Koperasi (Studi Empiris pada Koperasi-Koperasi yang Terdaftar di Dinas Koperasi dan UKM Pontianak Tahun 2014). Penelitian tersebut menunjukkan hasil bahwa aset tidak berpengaruh secara signifikan terhadap SHU.

Aset tidak berpengaruh signifikan secara parsial terhadap SHU pada KJKS Ben Iman Lamongan disebabkan karena SHU dipengaruhi oleh biaya-biaya yang dikeluarkan oleh koperasi. Aset sangat penting bagi koperasi sehingga memerlukan pemeliharaan atau perawatan, terutama pada aset tetap agar nilai ekonomisnya terus terjaga. Namun, pemeliharaan aset tentu memerlukan sejumlah biaya. Apalagi jika dalam penggunaan aset tidak sesuai aturan atau seenaknya pasti akan menyebabkan kerusakan pada aset tersebut dan menimbulkan biaya yang lebih besar. Sehingga aset yang seharusnya berpengaruh signifikan secara parsial terhadap SHU tidak didapatkan. Bahkan antara aset dan SHU pada KJKS Ben Iman Lamongan memiliki hubungan negatif, di mana jika aset mengalami kenaikan maka SHU akan mengalami penurunan dan sebaliknya. Jika aset mengalami penurunan, maka akan menaikkan biaya yang dikeluarkan. Jika biaya mengalami kenaikan, maka SHU 
Niswah, et al/Jurnal Ekonomi Syariah Teori dan Terapan Vol. 4 No. 12 Desember 2017: 937-951; FAKTOR YANG MEMPENGARUHI KENAIKAN DAN PENURUNAN SISA HASIL USAHA (SHU) KOPERASI SYARIAH

akan mengalami penurunan karena biaya dan SHU memiliki hubungan terbalik.

\section{Pengaruh Pendapatan Pembiayaan dengan Sisa Hasil Usaha (SHU)}

Pembiayaan menjadi penyumbang pendapatan terbesar pada koperasi syariah. Kegiatan pembiayaan menjadi kegiatan utama koperasi syariah terutama koperasi jasa keuangan syariah. Semakin besar pembiayaan yang dilakukan maka semakin besar pula total pendapatan yang akan diperoleh koperasi. Pendapatan yang besar akan membuat laba yang diperoleh juga akan semakin besar. Sebagaimana dalam penelitian yang dilakukan Ziqri (2009) tentang Analisis Pengaruh Pendapatan Murabahah, Mudharabah dan Musyarakah terhadap Profitabilitas Bank. hasil penelitian tersebut menyatakan bahwa pendapatan atas pembiayaan (murabahah, mudharabah dan musyarakah) berpengaruh secara signifikan terhadap profitabilitas bank syariah.

Pembiayaan yang dilakukan oleh anggota akan memberikan koperasi bagi hasil atas jasa yang telah diberikan dan masuk ke dalam pendapatan koperasi syariah. Pendapatan pembiayaan yang meningkat dapat meningkatkan jumlah Sisa Hasil Usaha (SHU) yang dibagikan kepada anggota koperasi karena SHU diperoleh koperasi syariah, dapat diperoleh dari total pendapatan dikurangi harga pokok penjualan, beban operasional, beban administrasi dan umum dan pajak penghasilan (Sitio dan Halomoan, 2001:92). Pendapatan pembiayaan koperasi syariah masuk ke dalam total pendapatan. Sedangkan total pendapatan proporsional dengan SHU, sehingga semakin besar pendapatan pembiayaan yang diperoleh oleh koperasi syariah, maka SHU yang diperoleh juga akan semakin besar.

Teori di atas mampu mendukung hasil uji $t$ parsial yang dilakukan dalam penelitian ini. Berdasarkan hasil uji $t$, didapatkan nilai $\dagger$ hitung dari variabel pendapatan pembiayaan sebesar 9,32 sedangkan nilai $t$ tabel sebesar 0,042 sehingga nilai $\dagger$ hitung lebih besar dari $\dagger$ tabel dan nilai signifikansi sebesar 0,000 atau lebih kecil dari 0,05. Dapat disimpulkan bahwa terdapat pengaruh yang signifikan secara parsial antara pendapatan pembiayaan dengan Sisa Hasil Usaha (SHU) pada KJKS Ben Iman Lamongan. Semakin besar pendapatan pembiayaan yang diterima KJKS Ben Iman Lamongan, maka SHU yang akan dibagikan ke masing-masing anggota juga akan semakin besar.

Pengaruh Modal Sendiri, Aset dan Pendapatan Pembiayaan dengan Sisa Hasil Usaha (SHU)

Berdasarkan uji $F$ simultan yang dilakukan, diperoleh nilai probabilitas (p) sebesar 0,000 di mana lebih kecil dari 0,05 dan nilai $F$ hitung 35,29 lebih besar dari $F$ tabel 2,92 sehingga terdapat pengaruh yang signifikan secara simultan antara modal sendiri, aset dan pendapatan pembiayaan dengan Sisa Hasil Usaha (SHU) pada KJKS Ben Iman Lamongan. Kemudian berdasarkan uji Koefisien 
Niswah, et al/Jurnal Ekonomi Syariah Teori dan Terapan Vol. 4 No. 12 Desember 2017: 937-951; FAKTOR YANG MEMPENGARUHI KENAIKAN DAN PENURUNAN SISA HASIL USAHA (SHU) KOPERASI SYARIAH

Determinasi $\left(R^{2}\right)$ didapatkan nilai $R^{2}$ sebesar 0,9313 yang berarti variabel modal sendiri, aset dan pendapatan pembiayaan berpengaruh terhadap SHU KJKS Ben Iman Lamongan sebesar 93,13\%. Sedangkan sisanya atau $6,87 \%$ dipengaruhi oleh variabel lain yang tidak diteliti pada penelitian ini.

Berdasarkan hasil uji regresi yang telah dilakukan, didapatkan model persamaan regresi berganda pada penelitian ini sebagai berikut:

$$
\begin{aligned}
Y= & (70,90 e+08)-0,0204601 X_{1}-0,0241663 X_{2} \\
& +0,2828628 X_{3}+\text { et }
\end{aligned}
$$

Persamaan ini dapat digunakan untuk memperkirakan jumlah SHU koperasi syariah dengan cara memasukkan (mensubstitusikan) pendapatan pembiayaan pada $X_{1}$, modal sendiri pada $X_{2}$ dan total aset pada $X_{3}$ dalam persamaan tersebut.

\section{SIMPULAN}

Berdasarkan data dan hasil analisis yang telah dilakukan, maka dapat ditarik kesimpulan sebagai berikut:

1. Modal sendiri tidak berpengaruh signifikan secara parsial terhadap Sisa Hasil Usaha (SHU) pada KJKS Ben Iman Lamongan.

2. Aset tidak berpengaruh signifikan secara parsial terhadap Sisa Hasil Usaha (SHU) pada KJKS Ben Iman Lamongan.

3. Pendapatan pembiayaan berpengaruh signifikan secara parsial terhadap Sisa Hasil Usaha (SHU) pada KJKS Ben Iman Lamongan.
4. Modal sendiri, aset dan pendapatan pembiayaan berpengaruh signifikan secara simultan terhadap Sisa Hasil Usaha (SHU) pada KJKS Ben Iman Lamongan sebesar $93,13 \%$, sedangkan sisanya $6,87 \%$ dipengaruhi oleh variabel lain yang tidak diteliti oleh penulis.

SARAN

Berdasarkan hasil penelitian dan kesimpulan di atas, maka saran yang dapat diberikan adalah sebagai berikut:

1. Hendaknya KJKS Ben Iman terus memaksimalkan promosi pembiayaanpembiayaan yang ditawarkan sehingga pendapatan pembiayaan yang didapatkan semakin banyak dan dapat meningkatkan Sisa Hasil Usaha (SHU) koperasi.

2. Hendaknya KJKS Ben Iman menjaga aset yang dimilikinya sehingga tidak akan menimbulkan biaya yang besar untuk pemeliharaannya, karena kenaikan biaya akan menurunkan jumlah SHU yang didapatkan koperasi.

3. Hendaknya KJKS Ben Iman lebih terbuka akan anggota baru dan terus meningkatkan promosi akan keuntungan menjadi anggota koperasi, sehingga jumlah anggota dapat meningkat.

4. Untuk peneliti selanjutnya, diharapkan mampu mengembangkan penelitian dengan tema sama dengan menggunakan variabel eksogen yang lain selain pendapatan pembiayaan, modal sendiri dan aset yang dapat mempengaruhi Sisa Hasil Usaha (SHU) pada koperasi syariah. 


\section{Daftar Pustaka}

Badan Pusat Statistik. (online). www.bps.go.id, diakses pada 25 Oktober 2016.

Buchori, Nur Syamsudin. 2012. Koperasi Syariah: Teori dan Praktik. Banten: Pustaka Aufa Media.

Burhanuddin. 2013. Koperasi Syariah dan Pengaturannya di Indonesia. Malang: UIN-MALIKI PRESS (Anggota IKAPI).

Departemen Agama RI. 2005. Al-'Aliyy: Al Quran dan Terjemahnya. Bandung: Diponegoro.

Ikatan Akuntansi Indonesia. 2007. Standar Akuntansi Keuangan Per 1 Semptember 2007. Jakarta: Salemba Empat.

Nafisa, Tsara. 2015. "Faktor-Faktor yang Mempengaruhi Modal Sendiri pada Koperasi". Skripsi Fakultas Ekonomika dan Bisnis Universitas Diponegoro (online). eprints.undip.ac.id, diakses pada 19 Januari 2017.

Purwanto, Maurisius Diki. 2015. "Pengaruh Modal Sendiri, Hutang, Volume Usaha, dan Jumlah Aset terhadap Sisa Hasil Usaha Koperasi (Studi Empiris pada Koperasi-Koperasi yang Terdaftar di Dinas Koperasi, dan UKM Pontianak Tahun 2014)." Jurnal Manajemen Update 4.4 (online). jurnal.untan.ac.id, diakses pada 19 Januari 2017.

Republik Indonesia. UndangUndang Dasar 1945.

Sari, Agustin Rusiana dan Beny Susanti. 2012."Pengaruh Modal Sendiri, Modal Luar, dan Volume Usaha pada Sisa Hasil Usaha Koperasi di Provinsi Daerah
Istimewa Yogyakarta." Fakultas Ekonomi Unisbank: Seminar Nasional dan Call For Papers (online). eprints.unisbank.ac.id, diakses pada 19 Januari 2017.

Sholihin, Ahmad Ifham. 2008. Buku Pintar Ekonomi Syariah. Jakarta: PT Gramedia Pustaka Utama.

Sitio, Arifin dan Halomoan Tamba. 2001. Koperasi: Teori dan Praktik. Jakarta: Erlangga.

Subagyo, Ahmad. 2015. Manajemen Operasi Lembaga Kevangan Mikro Syariah. Jakarta: Mitra Wacana Media.

Sugiri, Slamet dan Bogat Agus Riyono. 2008. Akuntansi Pengantar 1. Yogyakarta: Unit Penerbit dan Percetakan Sekolah Tinggi IImu Manajemen YKPN.

Supriyanto, Agn. 2015. Tata kelola Koperasi Kredit atau Koperasi Simpan Pinjam. Yogyakarta: CV Andi Offset.

Wibisono, Dermawan. 2003. Riset Bisnis: Panduan bagi Praktisi dan Akademisi. Jakarta: Gramedia Pustaka Utama.

Winarko, Sigit Puji. 2014. "Pengaruh Modal Sendiri, Jumlah Anggota, dan Aset Terhadap Sisa Hasil Usaha pada Koperasi di Kota Kediri". Nusantara Of Research, $\quad 1.02$ (online). efektor.unpkediri.ac.id, diakses pada 30 November 2016.

Windarti, Sri. 2010. "Analisis Faktor-faktor yang Mempengaruhi Sisa Hasil Usaha (SHU) pada KPRI di Kabupaten Wonogiri Tahun 2009". Doctoral dissertation, Universitas Sebelas Maret (online). eprints.uns.ac.id, diakses pada 30 November 2016. 
Niswah, et al/Jurnal Ekonomi Syariah Teori dan Terapan Vol. 4 No. 12 Desember 2017: 937-951; FAKTOR YANG MEMPENGARUHI KENAIKAN DAN PENURUNAN SISA HASIL USAHA (SHU) KOPERASI SYARIAH

Wiyono, Slamet dan Taufan Maulamin.

2012. Memahami Akutansi Syariah di Indonesia. Jakarta: Mitra Wacana Media.

Ziqri, Muhamad. 2009. "Analisis Pengaruh Pendapatan Murabahah, Musharabah dan Musyarakat terhadap Profitabilitas Bank." Skripsi Universitas Islam Negeri Syarif Hidayatullah Jakarta (online). repository.uinjkt.ac.id, diakses pada 15 Januari 2017.

\section{LAMPIRAN}

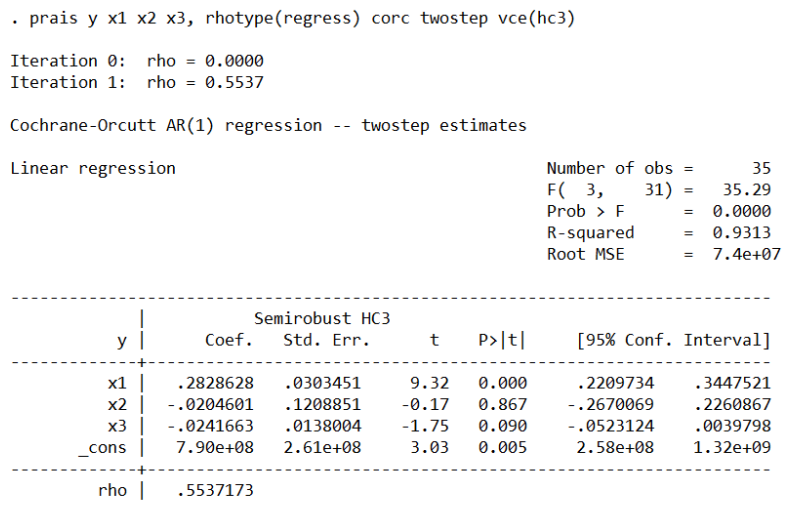

Durbin-Watson statistic (original) 0.830922 Durbin-Watson statistic (transformed) 1.974661 